\title{
Functional and Territorial Differences of Post- Communist Elections in Romania
}

\author{
Voicu Bodocan, Cluj-Napoca*
}

with 5 figures in the text

\section{Content}

Summary 499

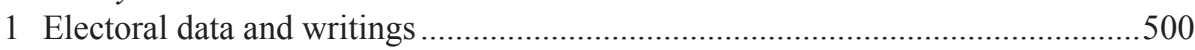

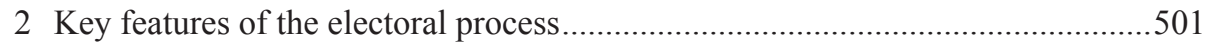

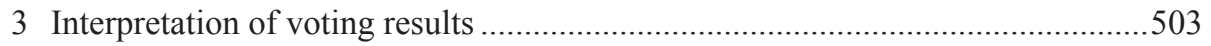

4 Political volatility versus geographical stability ...............................................504

5 Territorial differentiations: from political to administrative and

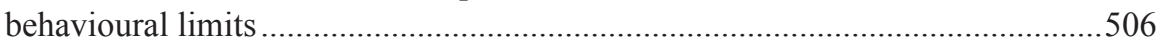

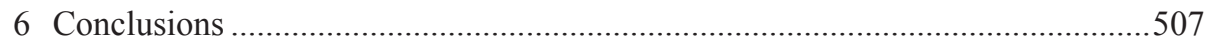

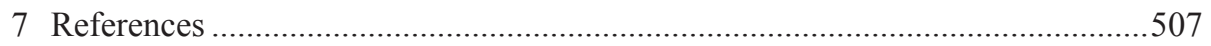

\section{Summary}

The aim of the paper is to explain the different voting behaviour models in postCommunist Romanian elections and to identify main factors of territorial differentiation of the results. Analysis is made for multiple parliamentary and presidential elections at communal, regional and national level. Various voting choice theories are applied to explain electoral behaviour and related to socio-demographic characteristics, economic variables and cultural features of the population. Territorial stability and electoral volatility are identified as results of cleavages within society, historical paths, post-Communist socio-economic development and regional diversity.

* Voicu Bodocan, PhD., Babeș-Bolyai University, Faculty of Geography, Strada Clinicilor 5-7, RO-400006 Cluj-Napoca, Romania; email: voicu@geografie.ubbcluj.ro 


\section{Electoral data and writings}

Democratisation of Romania as well as of the rest of East European countries represents a chance for the exploration of electoral behaviour after half a century of missing interaction between electors and their representatives. The field of electoral studies in Romania comprises the elections from 1990 to 2014: seven parliamentary and presidential, six local elections and two for the European Parliament. Are these enough to define a model of Romanian electoral behaviour? Models of electoral geographies are based on a larger range of elections and statistical data, not only on a 25-year transition period. Moreover, local and European elections are less relevant for explaining spatiality of voting due to local political programs, candidates and party identification and a lower turnout with European elections. The unstable party system and the volatile electoral coalitions make it also difficult to identify patterns of voting in some of the regions. Unfavourable political conditions following the financial crisis of 2008 had a serious impact on electoral behaviour, especially by protest voting.

Starting with 1990, Romanian elections became an issue in research of historians, sociologists and political scientists, but only a few have ended up in publications and many of them without a sufficient 'geographical' content. Sporadic geographical analysis was made of certain elections (PoP \& BodocAn 1991; GrozA 2001; IAȚU 2007; BoAmfa 2011 etc.) focusing on spatiality of voting. Substantial research on electoral behaviour in relation to cultural features of historical provinces was presented on Crișana-Maramureș by Ilieș (1998), Banat by CREȚAN (1999), Transylvania [Ardeal] by Bodocan (2001) and Dobruja [Dobrogea] by GiUgăL (2013). The most comprehensive work was recently finalised by a group of geographers, sociologists and political scientists led by Cornel IAȚU titled "The Electoral Atlas of Romania" (2014). Transnational studies made by foreign geographers were focused mainly on Central Europe (Poland, Czechia, Hungary and Slovakia) and to a lesser extent to Romania, often considered to be a different case (due to religion and middle class) even if most of the cleavages are to be found in this entire region. The Atlas of Eastern and Southeastern Europe, edited by Peter JORDAN, however, contains maps of Central and Southeast Europe plus explanatory texts showing the results of the first round of democratic elections in 1990 (parliamentary and presidential elections; JORDAN \& Schappelwein et al. 1991) and in a comparable way of the elections in 1994-1997 (Jordan, Mangott \& Schappelwein et al. 1998).

Due to the small number of elections and few publications in this field, it is too difficult to develop a geographical model of Romanian elections, and our research will thus be confined to a general approach to spatial voting patterns in the analysed period. 


\section{Key features of the electoral process}

The electoral process of these decades was characterised by divisions between parties representing the main cleavages and also by divisions within political parties and coalitions (Democratic Convention of Romania in 1996, Youth and Justice in 2004, and Social-Liberal Union in 2012). The party system and the electorate were bi-polarised by a Left/Right divide from the earliest democratic elections due to the Communist/anti-Communist conflict. This polarisation was also reflected at the level of presidential elections by Ion Iliescu from 1990 to 2000 and Traian Băsescu from 2004 to 2014. Due to their importance in Romanian political life, the popularity of the presidents determined sometimes the majority in the parliament (BoDOCAN 2014).

The main issues of the campaigns differed, from denial of Communism and nationalism in 1990, 1992 and 1996, to corruption in 2000 and 2004, perception of the candidates in 2008, 2009 and 2014, to macro-economic and personal welfare in 2012. The last elections of 2014 recorded an atypical result due to the issues and the efficiency of the campaign. Regional issues did not dominate any national electoral campaign, with the exception of the case of the Roșia Montană gold mine project. Foreign politics as well did not have a major impact, European and Euro-Atlantic integration and the relation with the Russian Federation and the Republic of Moldova being considered in the same way by almost all political forces.

Despite the stable electoral system, based on proportional representation, and a substantial system change in 2008 but with limited impact on electoral behaviour (only in representation, resulting in an oversized parliament), electoral volatility was quite high and a change of power took place almost after all elections (1996, 2000, 2004, 2012).

Age, gender, education and ethnicity in the first decade and well-being and professional structure afterwards (economic or retrospective voting) were the main social factors influencing the Romanian electorate.

As in many other European post-Communist countries, the turnout decreased constantly with every new election, the phenomenon being more accentuated with urban population (Fig. 1) and the western part of Romania, i.e. Banat and Transylvania, but also in Moldova. Divergence in turnout led, when the new electoral system was adopted, to some regional differentiation in representation. 
Figure 1: Evolution of the turnout between 1996 and 2012 (\%)

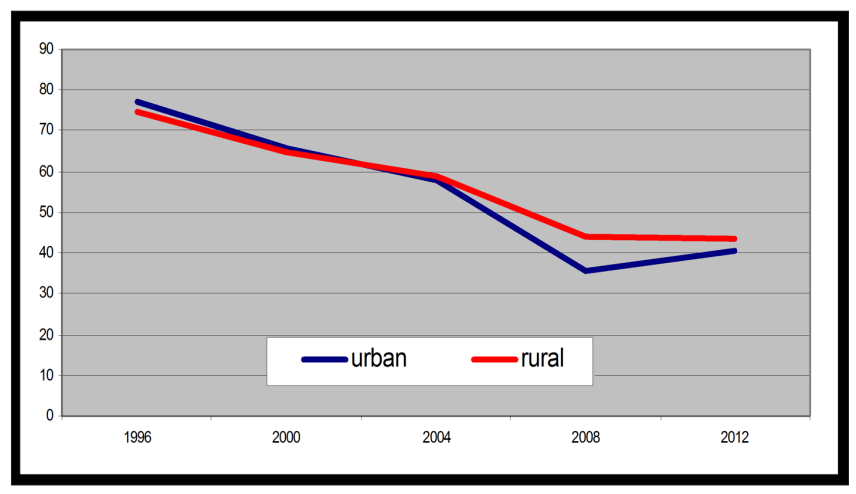

Source: Institutul National de Statistica

Figure 2: Turnout change in 2012 as compared to 1992 in legislative elections by major historical provinces

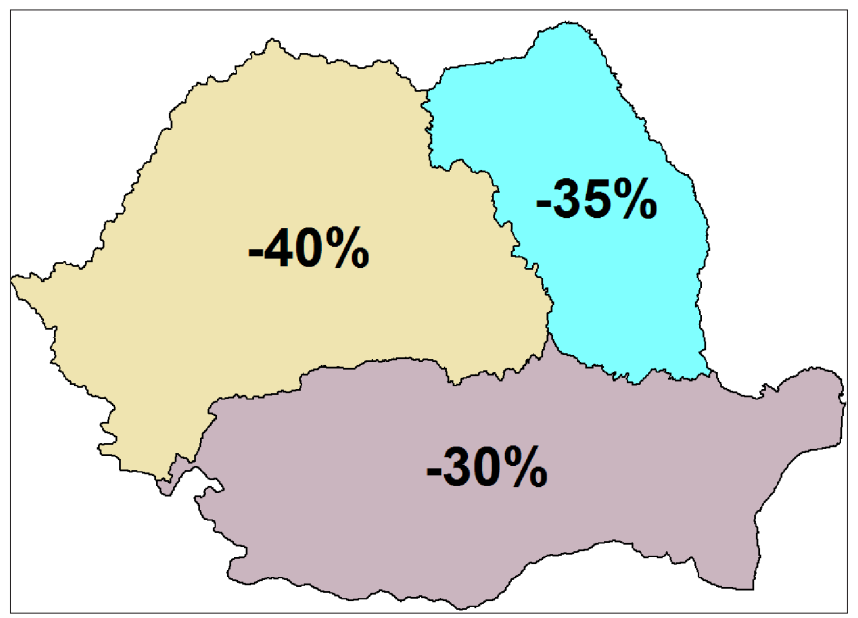

Source: Institutul National de Statistica 


\section{Interpretation of voting results}

Voting choice theories like the ecological, psychological or economic model of explanation may be applied in order to understand different patterns of voting in Romanian elections. The cleavage model (LIPSET \& ROKKAN 1967) was considered the main theory of interpretation to be applied. The theory has its limitations for Central Europe in general (Kitschelt et al. 1999; SELIER 1999) and for Romania in particular. The most important factors questioning association with the original cleavage model developed in Western Europe are the different size of the fundamental processes that determined the cleavages, and especially discontinuation marked by the Communist period. In Romania, some of the cleavages are even denied by political analysts. PREDA \& SoARe (2008), e.g., maintained that the industrial revolution did not produce the same cleavages in Romania as in Western Europe, this process being developed in Romania and other Eastern countries only later by the Communist regimes after World War II.

In terms of traditional politics, we can identify cleavages like Left/Right, centre/ periphery and urban/rural, but the ideological difference gets smaller and parties are more associated with their political actions and grass-root activities. At the same time, emotional affiliation with parties decreased in the last decade, especially on the right side of the political spectrum. From political voting (in association with Communism) in the first elections the behaviour has evolved towards economic voting, especially after the first change of power.

Figure 3: Cleavages in Romanian parliamentary elections by share of votes

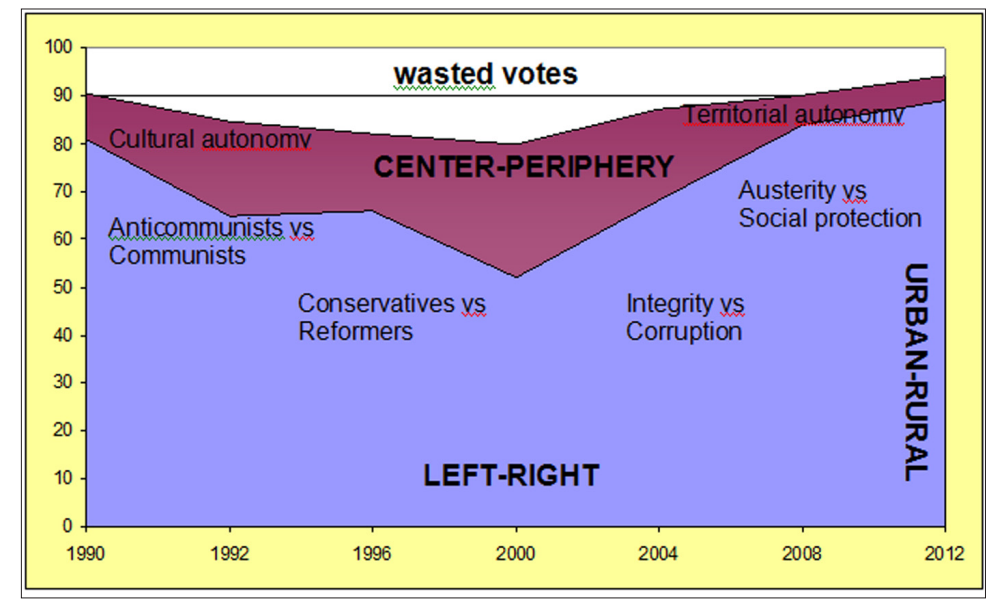

Source: Institutul National de Statistica 
Left/Right is the main cleavage in Romania. It was determined by the antiCommunist revolution as in most countries in the region and not by the industrial revolution. This conflict opposed structure-conservatives or post-Communists to reformers or anti-Communists and is the main conflict that bi-polarised Romanian society dominating electoral behaviour in all regions.

Centre/periphery was the second cleavage, dominant in some regions with a significant share of Hungarian population. The main issue proceeded from human rights and cultural autonomy towards political-territorial autonomy. The 'ethnic problem' has continuously decreased by the positive development of minority rights and by participation of the Hungarian party in many governments as a mainstream political party due to their flexible centre orientation.

The urban/rural dimension is represented by a social and economic divide and a difference in behaviour rather than by a political conflict. It is a projection of the Left/Right cleavage, since the difference between the rural and the urban electorate can be explained by the reformers/structure-conservatives cleavage. There is no agrarian party to represent peasants in Romania, a country with a large and consistent rural population and a lot of primary activities, this role being played by left SocialDemocrats in all elections.

\section{Political volatility versus geographical stability}

Despite political shift in the political arena, with four alternations of power and volatile coalitions, there is a remarkable territorial stability of voting preferences and political behaviour. Even if the main issues changed over time, electoral behaviour remained constant in many regions with a relatively consistent pattern of voting for candidates associated with a certain ideology or political program. More or less, we meet similar electoral geographies in many other countries of the region like Poland, Slovakia or Ukraine. All cleavages are projected on the territorial scale of historical provinces, minority regions and rural areas.

Regional disparities characterise all post-Communist elections. Differences between central and western regions and the rest of the country remain definitely obvious and the Left/Right cleavage appears as a historical divide between West and East. Thus, the most stable electorate characterises the Left and is to be found in Moldova and Wallachia [Ţara Românească], but also in some mining and isolated rural areas of Transylvania and Crișana (Hunedoara, Salaj, Bihor). Dominance or alternation of Right parties are specific for the historical regions Transylvania, Banat, Crişana, Maramureş and Bucovina, but also for parts of Dobruja and industrialised and urbanised Central Wallachia. 
Figure 4: Territorial stability of the Left and ethnic parties 1996-2004

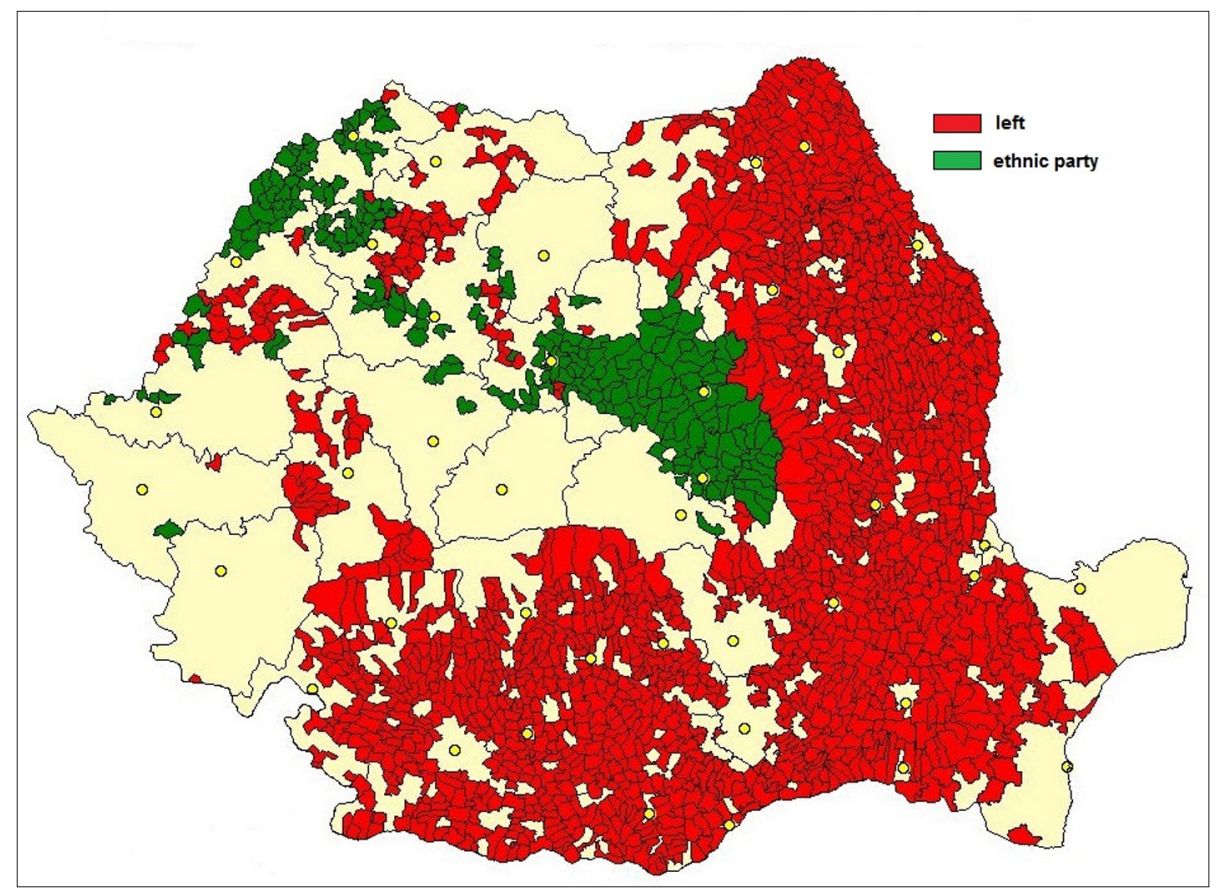

Source: Biroul Electoral Central

Cultural regionalism has produced a well-defined territorial differentiation and the centre/periphery cleavage is related to the presence of minority areas in Transylvania, Banat, Crișana, Maramureș, Bucovina and Dobruja. A marked difference exists between ethnically mixed and homogeneous areas (BoDOCAN 2003). The most stable electorate is that of the Hungarian community, with a constant support for their political parties. The Szeklerland represents the most stable electoral region of Romania. 
Figure 5: Territorial stability of Rightist and ethnic presidential candidates 20042014

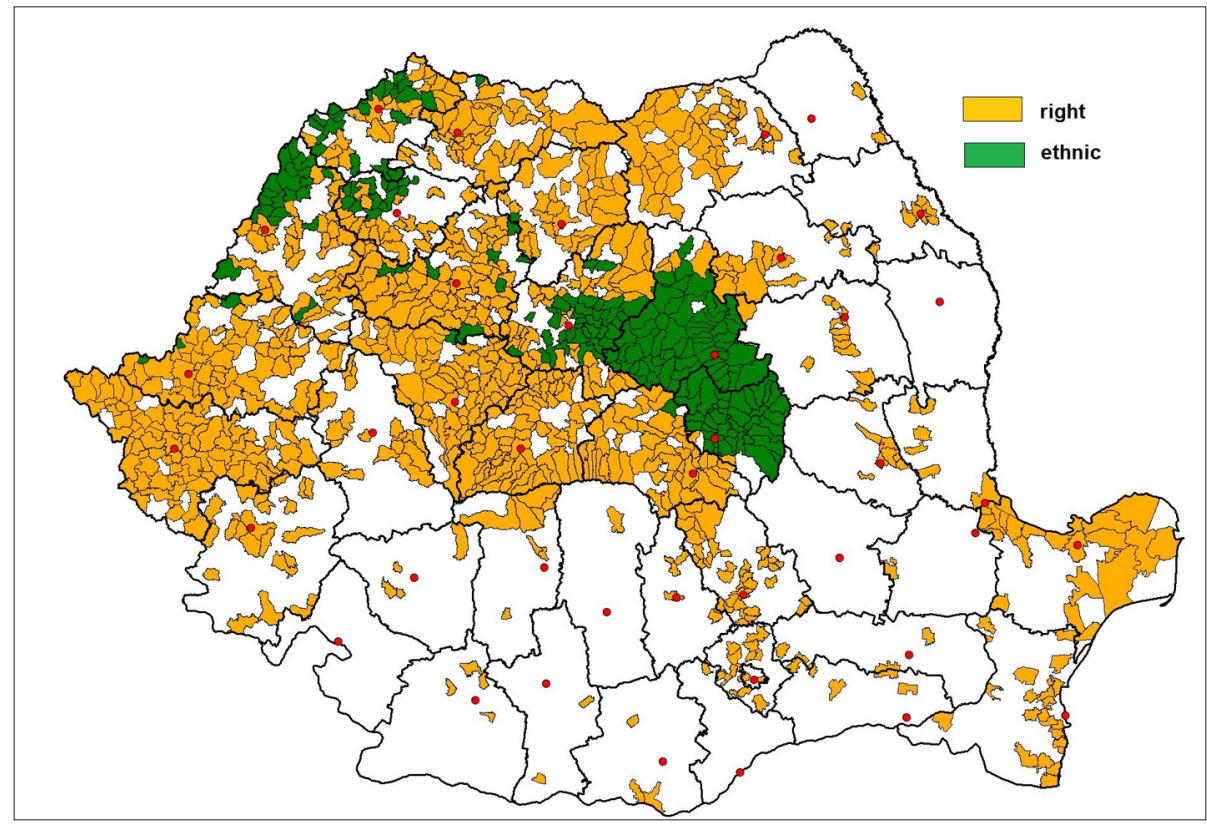

Source: Biroul Electoral Central

The urban/rural cleavage is obvious in many parts of the country, but especially in the southern and eastern parts, the rural areas within these regions remaining stable, monochrome. A stable urban support can be found also in the big cities and county capitals. Smaller towns resemble in electoral behaviour mostly the surrounding rural settlements (BODOCAN 2007).

\section{Territorial differentiations: from political to administrative and behavioural limits}

Electoral geography can contribute to the explanation of the geographical link between political attitude and regions and to answer in the particular case of Romania why the Left/Right cleavage is so territorially defined and why the Left is so stable in the East and South.

Despite the levelling, standardisation and globalisation processes, which affected most of the society, territorialisation of voting is still strong. Proximity is still important 
and Communism has not removed regional disparities. Historical impacts are the main model of explanation. Historical political experiences, with modern Romania covering former Ottoman and Habsburg possessions, remained visible in socio-structural characteristics, which are the main variables in territorial differentiation of electoral behaviour. Former political boundaries turned into social and cultural limits. But this bi-coloured map did not produce territorial adversity like in other countries (e.g. Italy, Ukraine) despite differences in development and territorial identities. Place did not produce parties ignoring national interests and did not prove to be a catalyst for political movements.

Research on social development at local scale (SANDU 2011) found strong correlation with political attitudes. Regional differentiation of some indicators (education, ageing, life expectancy, dwelling area, energy consumption, number of cars/1,000 inhabitants, size and rank of settlements) shows clear differences between the western provinces and the Old Kingdom and similarities between Transylvania, Banat, Crișana-Maramureș as well as between Moldova, Muntenia, Oltenia.

\section{Conclusions}

Romanian electoral geography is well-defined by the general characteristics of the wider post-Communist region but also by specific processes and phenomena. Territorialisation of voting is one of the strongest in Europe and it can be explained as a consequence of different historical experiences. Parties will draw their votes always from the same regions and our interest as geographers should continue to be focused on the explanation of territorial differences based on modern and classical methods of spatial, social and political sciences. Aspects of socio-economic disparities, cultural evolution and territorial diversity should be considered. Social remittances by transfer of cultural models and the role of diasporas as well as of non-territorial actors like social media are of special interest as regards the last presidential elections. All this analysis may lead to a re-conceptualisation of the models of electoral behaviour.

\section{References}

BoAmF $\check{I}$ I. (2010), Mapping of the Elements of Electoral Geography. Case Study: Parliamentary elections in Romania and in the Republic of Moldova after 1989. In: Revista Română de Geografie Politică, XII, 2, pp. 189-205.

Bodocan V. (2001), Etnie, confesiune şi comportament electoral în Transilvania. Cluj-Napoca, Editura Presa Universitară Clujeană. 
Bodocan V. (2003), The Multidimension of Electoral Behavior in Transylvania. In: BenedeK J., Schultz E. (eds.), Südosteuropa. Geographische Entwicklungen im Karpatenraum (= Würzburger Geographische Manuskripte, 63), pp. 29-37. Würzburg, Institut für Geographie.

Bodocan V. (2007), Electoral Behavior in Rural Areas in Romanian Last Elections. In: Revista Română de Geografie Politică, IX, 1, pp. 5-11.

Bodocan V. (2014), Presidential Elections 2009 in Romania. In: Jordan P. (ed.), Atlas of Eastern and Southeastern Europe, 6.3-R4, Stuttgart, Borntraeger.

Crețan R. (1999), Etnie, confesiune şi comportament electoral în Banat. Timişoara, Studiu geografic, Universitatea de Vest.

GiUgĂL A. (2013), Geografia electorală a Dobrogei postcomuniste: 1992-2012. Cluj-Napoca, Editura fundației pentru Studii Europene.

Groza O., Trofin-Gille C. (2001), Les élections roumaines: le poids du passé. In: Revue Belge de Géographie, 1-2, pp. 125.

IAȚU C. (2007), Transition démocratique en Roumanie et implications spatiales - The territorial consequences of democratic transition in Romania. In: L'Espace Politique, revue en ligne de géographie politique et géopolitique - online journal of political geography and geopolitics, 3 .

IAȚu C. et al. (eds.) (2014), Atlasul electoral al României. Iaşi, Editura Universităţii „Alexandru Ioan Cuza" din Iaşi.

ILIEş A. (1998), Etnie, confesiune şi comportament electoral în Crişana şi Maramureş. ClujNapoca, Editura Dacia.

Jordan P., Schappelwein K., Suppan A., Koch K., Heuberger V. (1991), The Elections of 1990 in Central and Southeastern Europe. In: JoRDAN P. (ed.), Atlas of Eastern and Southeastern Europe, 6.1-G3. Stuttgart, Borntraeger.

Jordan P., Mangott G., Schappelwein K., Heuberger V. (1998), The Elections of 1994-1997 in Central and Southeastern Europe. In: JoRDAN P. (ed.), Atlas of Eastern and Southeastern Europe, 6.2-G5. Stuttgart, Borntraeger.

Kitschelt H., Mansfeldova Z., Toka G., Markowski M. (1999), Post-Communist Party Systems: Competition, Representation, and Inter-Party Cooperation. Cambridge, Cambridge University Press.

Lipset S.M., Rokkan S.E. (eds.) (1967), Party Systems and Voter Alignments: Cross-national Perspectives. New York, Free Press.

Preda C., Soare S. (2008), Regimul, partidele şi sistemul politic din România. București, Nemira.

SANDU D. (2011), Dezvoltarea regională în România. Granițe socioculturale în mișcare, în Dezvoltarea capitalului comunitar în România <http://audieri.advocacy.ro/sites/audieri. advocacy.ro/files/files/pagini-audiere/documente_conexe/2012-11/2011_sandu_d_ dezvoltarea_regionala_in_romania.pdf $>$

SeILER D.L. (1999), Partidele politice din Europa. Iaşi, Institutul European. 